\title{
Aspekte van reg en geregtigheid met betrekking tot gevangenes*
}

\author{
JAN H. VAN ROOYEN \\ Depaitement Straf-en l'rosesreg, IINISA, I'retoria
}

ARSTRACT

It is submilled that all scientific labour rests on certain presuppositions. It is further submilted that academics should stale their presuppositions explicilly and also indicate the consequences thereof. Especially when the conrepts of "justice" or "human rights" are involved, the value system (and its underlying presuppositions) against which the inles of lavo in question are to be measured, should be slated clearly.

The presupposition of a naturalistic (materialistic) point of departure is that everything is malter and that everything is the product of the "impersonal" plus "time" plus "chance". Upon such a foundation no meaningful view of human rights can be comstructed. Against this, the Biblical presupposition is presented of a personal Creator(ind who crented man in Wis image. With such a universal, the particulars also have meaning, and there is a solid foundation for concepts of human rights.

Next, the South African legal position is sketched. Our prison law distinguishes between prisoners' rights and their privileges. Regarding the latter, the commissioner of prisons has virtually an absolute discretion. Two case sludies are presented: the histories relating to (a) study privileges and (b) reading malerial for security prisoners ("political" prisoners).

Afler the concept of the iamge of God (imago Dei) in man is examined, it is submitled that the content of our prisoners' rights does not reflect this adequately.

The requirement that the authorities should also be under law, is analysed as a Biblical requirement. Some implications of this are indicaled: (i) clear and comprehensive rules and (ii) control by an independent judicial arbiter. Also in these respects our present system falls short.

- Oorgenecm uit Tydskrif wir Hedendaggre Romeins-Hollandse Reg, 44(1) Feb. 1981.

Kiners, $46(3) 1981$ 


\section{Geregtigheid met betrekking tot gevangenes}

The retributive basis of justice requires inter alia that only the truly guilly be punished. Depriving whole calegories of people, e.g. "security prisoners", of their vights or privileges because of abuse by a few persons does not conform to principles of justice.

In accordance with the Biblical concepl of grace, no one may be "wrillen off" as beyond rehabilitation. Since most security offenders will evenlually be released back lo sociely again, they ought to be allowed post-matric study privileges while in prison.

In conclusion it is suggested that we should move away from a system of virlually absolute discretion towards a system of maintaining legality and justice, and that the content of prisoners' rights be expanded to accord fully with the Biblical concept of "man crealed in the image of God".

Onder blyke van groot belangstelling is daar gedurende Junie 1980 'n vereniging vir die bevordering en handhawing van menseregte in SuidAfrika gestig. Dit het gevolg op 'n belangrike internasionale kongres oor menseregte wat in Januarie 1979 by die Universiteit van Kaapstad gehou is. In verskeie lande het die belangstelling in menseregte uitgekring om ook gebiede wat voorheen verwaarloos was, te dek. Een van hierdie gebiede is dié ten opsigte van regte van gevangenes'. Daar is tekens dat hierdie nuw'e belangstelling ook sy spore in Suid-Afrika gaan naluat ${ }^{2}$.

'n Faktor wat ongetwyfeld meegehelp het om die belangstelling in die regte van gevangenes in Suid-Afrika gaande te mak, is die lotgevalle van namatriekstudievoorregte van sekerleidsgevangenes (dic sogenoemde "po-

I Daar word in hierdic bydrae primér aandag geskenk aan genonniste gevangenes en nic: onverhoorde aangehoudenes kragtens alie etu of andel sekerheidsinaatreel nie.

2 Onlangse bydraex in Suid-Afrikaanse legstydskilie sluit in: Huler 1978.S.1.SK 229; Van Wyk

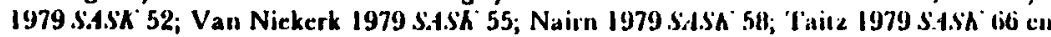
Kudolph 1979.SALJ 640. Op 5 Junie I9A0 is "u simposium "Focus on Prison", waaraun onteJ andere twee regten deelgeneem het, by die (Jiversiteit van Natal iı Durban gelwu. M l, t die beskerming van menseregte in 'n administratiewe stat, verwys (iellhorn in die vel slag Iluman Kights: The Cape Toun Conference (1979) 177181 e v spesiliek sa die regte van

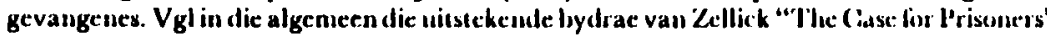
Riglıts" in Freman (red) Prisonr Past and Puture (1978). 


\section{Jan II. van Rooyen}

liticke" gevangenes). Regulasie 109 van die gevangenisrcgulasics (GK R2080 van 31 Descmber 1965 , soos gewysig) maak daarvoor voorsiening dat gevangenes in dic diskresic van die kounmissaris van gevangenisse gedurende hul vrye tyd in gevangeneskap) verder mag studecr. Heclparty sckerheidsgevangenes het dan ook hul tersiêre opleiding deur instellings soos Unisa voortgesit.

Vrocg in 1978 is egter 'n beleidsveraudering deur die minister van gevangenisse in dic parlement aangekondig ${ }^{3}$ : sckerheidsgevangenes word in beginsel ná-matrickstudievoorregte ontneem. Dric redes is vir hierdie beleidsverandering gegec: (a) Sekerheidsgevangenes misbruik hul studiegeleenthede deur st udiematcriaal vir opruiende geskrifte, aauhitsing en smokkelary na buite tc gebruik; (b) dic departement sc personceltckort bemoeilik die tocpassing van behoorlike bcheermatteèls; en (c) gevangenes wat wel na-matrickstudievoorregte verwerf het, het na hul vrylating hul ondermyncnile bedrywighede plaaslik voortgesit of na dic buiteland uitgewyk en dit vandaar voortgesit'. I ie minister loet ook verklaar dat sekerheidsgevangenes nic vir rehal,ilitasic vatbaar is nie $\mathrm{e}^{5}$.

Op Robbenciland alleen is daar tans ongeveer 492 gevangenes weens misdarle teen die staat ${ }^{6}$.

Op grond van vrae wat na die minister se verduideliking gevra is, blyk dit dat slegs vier gevangenes op Robbenciland hul ná-matriekstudievoorregte in 1977 misbruik het. Dit blyk ook dat, gedurende die tien jaar voor 1978 , slegs lien sekerheidsoortreders na hul vrylating weer weens oortredings teen die staatsveiligheid veroordeel is; nie een van dié tien het egter ná-matrickkwalifikasies in die gevangenes verwerโ nic! Gedurende dieselfde tien jaar het scwe en vecrtig oud-sekerheidsgevangenes die land verlaat, van wie slegs twaalf na-matrickkwalifikasics in die gevangenes verwerf het?

\footnotetext{
Kyk 1978 (15) Mansard kolorn 6980 (Nir.)

197A (2) Mansard vrackolom 102 ( $\Lambda$ ir.)

"Dehates of the Slanding Commillee on the Approprintion Bill: Vole 24 - "Prisons" (standing commillee vrackoloun 778.

- I980 (12) IInnsard vrackolom 733-734 (Eng.).

, 1978 (18) Hansard vrackolom (B47-818) (Afr.)
} 


\section{Geregtigheid met betrekling tot gevangenis}

Gedurende 1978 is verdere pogings aangewend om inligting te lsckom met betrekking tot die feitlike grondslag vir die minister se verduideliking. Die volgende vrae is per brief aan die kommissaris van gevangenisse gestel:

1. Hoeveel sekerheidsgevangenes te Robbeneiland liet gedurende 1977 ná-matriekstudievoorregte geniet?

2. Hoeveel sekerheidsgevangenes in alle iurigtings het jaarliks gedurende die afgelope tien jaar (a) ná-mat rickstudievoorregte gehad; (b) ná-matriekkwalifikasies behaal?

3. (a) Hoeveel sekerheidsgevangenes is jaarliks gedurende die afgelope tien jaar vrygelaat?

(b) Hoeveel van hierdie gevangenes wat jaarliks vrygelaat is, het loe fulle nog in die gevangenes was (i) ná-matriekstudievoorregte gehad; (ii) nd-matriekkwalifikasies behaal?

4. (a) Hoeveel sekerheidsgevangenes is jaarliks gedurende die afgelope tien jaar opgeneem?

(b) Wat was die daaglikse gemiddelde aantal sekerheidsgevangenes jaarliks gedurende dieselfde tydperk?

Die kommissaris het geantwoord dat, aangesien sy departement "geen belang daarby het" om die verlangde gegewens te laat publiseer nie, hy nic geneè is om dit beskikbaar te stel nie.

Gedurende 1979 is vertož, sonder sukses, deur verskillende instansies aan dic gevangenisowerhede gerig om die beleidsverandering in heroorweging te neem. 'n "Gevangenes-opvoedingskomitee" is in die lewe geroep en het gepoog om ' $n$ afvaardiging onder leiding van aartsbiskop Denis Hurley van Durban na die minister te stuur, wat egter geweier het om hulle te woord te staan".

Vroeg in 1980 het die minister in die parlement in antwoorl op 'n viaing verklaar dat hy nie in die stadium bercid is on dic na-matrickstuelievoorregte weer toe te staan nie ${ }^{9}$. Drie maande later kondig liy egter aan dat daar besluit is om ná-matriekstudievoorregte vir kwalifisereude sckerheids-

- Prelaria Nerus (1979-12-18).

- 1940 (1) Hansard vrackolom 15 (Eing.) 


\section{Jan H. van Rooyen}

gevangenes wecr in te stel ${ }^{10}$. Dić besluit is allerweè verwelkom, alhoewel dic wete nat uurlik claar is dat dic beleirl te eniger tyd wécr verander kan word.

Die hele verloop van dic ná-matrickstudievoorregte-geskicdenis het sckere algemene vrac oor reg en geregtigheid met betrekking tot gevangenes in Suid-Alrika skerp na vore gebring. Kernpunte wat in hierdie bydrac kortliks beskou sal word, sluit in:

- dic aanvaarbaarheid van die huidige onderskeid tussen en inhoud van sogenoemde "regte" en "voorregte" in die Suid-Afrikaanse gevangenisreg;

- dic tocpassing van die legaliteitsheginsel in die gevangenisopset;

- die vercistes van geregtigheid by dic ontucming van regte en voorregte; $c n$

- aspekte van rehahilitasie binne gevangenisverband.

In hierdie bydrac word met betrekking tot sekerheidsgevangenes die volgendc aannames gemaak: (a) hulle is behoorlik skuldig bevind en gevonnis weens misdade teen dic staat; (b) hulle "verdien" die opgelegde gevangenisstraf (maar nie byvoorbecld dic doodstraf nic); (c) die mecste van hulle sal inctlertyd na die gemeenskap terugkcer.

Hierdic bydrac handel nic net oor reg ("law") nie, maar ook oor gcregtigheid ("justice"). Hy geregtigheid gaan dit oor (a) die inhoud van regsrcèls, asook (b) die prosessuele loepassing van regsreëls". Die massa literatuur oor hierdie moeilike onderwerp in die regsfilosofic val buite die bestck van hierdie bydrac. Hahlo en Kahn - en ander skrywers konkludeer dat "possibly only a religious basis can give a genuine foundation for the absolute iclcals of justice, and religion is based on revelation and faith"'12. Hosten $/$ al dui aan dat geregtigheid neerkom op'n aanvaar bare verhouding tussen 'n regsreël en die waardestelsel wat as norm gekics is om die regsreël tc evalucer. Oureg ("injustice") bestaan wannecr die regsreël,

1" 1980 (13) Hansayd kolom 6129-6130 (Eng.). Die minister het terselfidertyd aangekondig dat daar voortaan 'n Engels- en 'n Afrikaanstalige kurrant aan dié gevangenis se biblioterk beskikbaar gestel sal word - ilid.

"Vort 135 sluit nok sowel die materiele imhoud as dic formele aanwending daarvan by sy definisie in .

12 Hahlo en Kahu, The South African Iegal. Sy:tem and itr. Rackground (1968) 30. Vgl. ook Hosten et al Introduction to South African Iaw and legal Thenry (1977) 22, veral vn 117; en vgl in dic algemecu dic verslag van dic Sprocas-regskommissic Law, Justice and Sonciely (1972) en Onsthuizen The lithics of Illegal Action (1973). 


\section{Geregtigheid met betrekling tot gevangenis:}

alhoewel dit self formeel geldig is, met dic betrokke waardestelsel bots ${ }^{13}$. Die waardestelsel vervul as 't ware die rol van 'n Hoër Reg - 'n Reg lokant die reg.

Van der Vyver konstateer dat "[a]lle welenskaplike arbeid ... op 'n geluojsuitgangspunt [berus], hoewel alle geloofsuitgangspunte [vansellsprekend] nie aan die Christelike belydenis georiënteer is nie ... [E]lke wysgerige stelsel [berus] op 'n bepaalde uitgangspunt of presupposilum ..."'t. Heel dikwels word die betrokke uitgangspunte of voorveronderstellings egter nic uitdruklik vermeld nie. In dié verband praat Dugard - in sy intreerede, meer as nege jaar gelede gelewer - van "inarticulate prenisses" 15 . Hy krit iseer die Suid-Afrikaanse regbank vir sy oënskyulike positivistiese benadering ten opsigte van sekere sensitiewe regsgebiede, toon aan dat daar nit werklik "objektiewe positivisme" kan bestaan nie maar dat regters deur luul versweë uitgangspunte of voorveronderstellings beïnvloed word, en bepleit dat die hele proses na die oppervlak gebring en bewustelik hanteer moet worl/ ${ }^{16}$.

In hierdie intreerede wil ek graag bepleit dat ook akademici hul voorveronderstellings en waardestelsels moet openbaar en aantoon welke invloed dit op hul (wetenskaplike) beskouings uitoefen. Hicrdic bydrac gaan dan ook spesifiek poog om nie 'n bleck, "neutrale" akademiese benaderiug te handhaaf nie, maar is gebaseer op delinitiewe voorverondetstelings en waardes, wat dan ook kortliks uiteengesit sal word.

13 Itosten et al supra 22. So ook talle ander skrywers. Vglo a l.loyd The Iteu of l.ane (I96t) I 222 cv.

"In Van der Vyver en Van Zyl Inleiding lot die Regsuetendap (1972) I.

"S Dugard 197I SAL.J I8I 187.

16 Ibid passin. 'n Belangrike onlangse studic toon duidelik aan dat regterlite lecanpters ste's deur "verskuilde faktore" (soos bul agtergrond, persoonlike lewemsilesedie, ens) beïuvloced word - Hogarth Sentencing as a Humun Process (1971, herdruk 1974) (geresensecer in 1979 S.ASK 307). Op grond van sy bevindinge konkfudecr by dat "Ile juclicial process is uot as uniform and impartial as many people would hope it would be. lndeed, it would appedr that justice is a very personal thing" (365). K $\mathbf{p k}$ in die algemeen ook lsollomley, (inminolugy in Fucus: Past Trends and Future Prospects. (1979) (gerescusecer in 1979 S.1.54 301), watat in 'it deurlopende tena is dal subjekt iewe wadardes (values) 'n sentrale robl in die kriminologic spect,

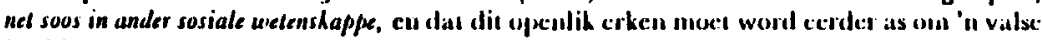
beeld van "wetenskaplike objektiwiteit" le probeer venuluon. 


\section{Jan H. van Rooyen}

\section{'N BYBELSE GRONDSLAG}

Mont gomery illustrecr dic belangriklıcid van 'n mens se filosofiese vertrekpunte met dic volgcusde anckdote: "Once upon a time a hare of philosophical temperament invited a politically orientated fox to dinner. During the entrece the hare presented an interesting argument on the relativity of all law and morals, st ressing that cach beast, in the final analysis, has a right to his own legal system. 'The fox did not find this argument entirely convincing on the intellectual level, but was much impressed with it practically. For clessert he ate the hare: lapin d la creme!" "17.

Iledendaagse voorstanders van 'n nie-positivisticse "Hoër Reg"-benadering basecr hul waardestclscls gewoonlik op 'n sosiologies-georiënteerde grondslag. So betoog Dugard dat daar'n behocfte is om gelei te word deur "accepted traditional legal values"18 te wetc "the jural postulates which form part of our legal heritage and are designed to foster the basic political and legal ideal of modern Western society - the well-being and free development of the individual"19. Insgelyks verklaar Van Nickerk dat Gustav Radbruch sy natuurregbenadering op 'n algehele toewyding aan die waarde en waardigheid van die mens toegespits het, "using as a foundation his a priori atlachment to certain idealist ic values" ${ }^{20}$. Dié idealist iese waardes word ontleen aan dic Westerse kultuur en die kultuur van "beskaafde" nasies ${ }^{2 !}$.

Ilierdie sieninge bring 'n mens by die kernvraag na die sin en belekenis van die hele menseregte-beskouing. Dit sluit aan by die groter vraag na dic betekenis van die lewe - 'n vraag waarmec die filosoferende of nadenkende (menscregte-) juris wel in die cen of ander stadium te kampe sal he ${ }^{22}$.

17 Moulgownery The Lawe Abme the Latu (1975) 17-1A.

in Dugard supura 195

10 idl 197.

t" Van Nirkerk 1973 SAI.7 123240.

"I idl 257 vn 99; vgl ook ill 249 (par no 5). Zylstrn het tydena die 1979-Kaapae menseregtekongrea gewys op die gevaic verbonte aan so 'n benadering en het 'n mecr fundamentele benadering Ioppleil - kyk Ihman Rights : The Ciape Toun Conference (1979) 46 vir 'n kurt "psomming van sy standpunt.

22 Vir 'n beskming (oor die noxolsaak vir elke juris om nor (regs-)rilosofie na te dink, kyk Du Plessis I9no Ite, Jure 22. 


\section{Geregtigheid met betrekking tot gevangenes}

Macnamara merk in dié verband op: "Ihe topic of ıneaning in life can be approached in either of two frames of mind: it can be seen as an abstract, purely intellectual exercise, or it can be examined as something at the core of life that must both be reflected on and - plainly - felt in the heart" 23

Die skrywer van hierdie bydrae gaan kortliks 'n siening wat hy as bevredigend in sy eie hart ervaar, weergee. Daar word onmiddellik erken dat hierdie beskouinge nie die eindresultaat van ondersoek en nadenke daarstel nie: dit is in werklikheid 'n begin. Waar die skrywer 'n sekere benadering bó ander verkies, kom dit nic neer op 'n arrogante alskrywing van andersdenkendes nie. Inteendecl, daar word erken dat, veral in die menseregteveld, kragte gesnoer en samewerking, waar moontlik, gesoek moet word ${ }^{24}$.

Die benadering in hierdie bydrae volg grootliks dié van Francis $\Lambda$ Sichactler en sy medewerkers' ${ }^{25}$. Uit die aard van die saak kan slegs 'n baie kursoriese oorsig gegee word.

In die eerste plek moet gewys word op sekere konsekwensies van 'i naturalistiese (in teenstelling met 'n Bylsels-teïstiese) beskouing. Dric aanhangers van dié wêreldbeskouing het die konsekwensies van hul sieninge uitgestippel, te wete Monod, Skinner en Blackham. Die liranse molekulềc bioloog, Jacques Monod, aan wie dic Nobelprys in 1965 toegcken is, staan in

23 In Macnanara (red) Meaning in Life (1977) 165.

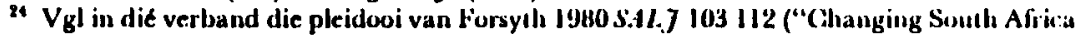
requires in my view the abilities and effors of all men of gend will; we ought mot lo ixe divided") na aanteiding van 'u afwysing van die hele sulstanticwe mu:nseregte-locnadering jeur Davis 1980 SAI.J 94.

25 Vir doeleindes van hierdie bydrae moet cersens ua Silhacller se trilogic The (jud who is There (1968), Escape from Reason (1968) en /le is There and I/e is not Silcat (1972) verwys word (daar is 'n studiehandleiding, Introduction to Francis. Schaelfer (1974), beskikbaar). Van lecsondete belang met betrekking tot menseregte is S'haeller en Koup th'hatever thappened to the thuman

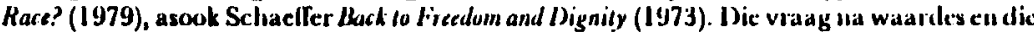
belekenis van die Iewe word meesterlik luchandel deur (ininnes The Dust of Death (1973) en Sire The Iniverse Next Dour: A Cuide lo It'urld I'icus (1976). Die volgende is, binne die luinlige

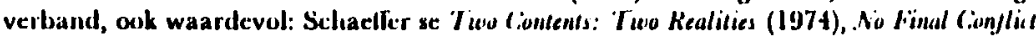
(1975), (ienesis in Space and Time (1972), en Jlow Should ll'e 'Then Live? - The Rise and lecaline of

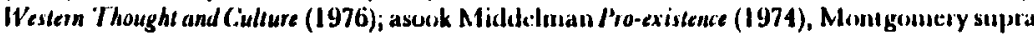
17-18, Anderson Morality, Law and (itace (1!72) en I.ewis The Abolition of A Ian (1943). Versanelings opstelle wat vershillende sienings rellekleer, is te vinte in Macmanara sujutil en in Macnamara (red) World Viecos (19R0) 


\section{Jan H. van Rooyen}

dic middelpumt van die Dar winiaans-naturalist iese lewensbeskouing, waarvolgens onder andere die mens dic result nat is van die onpersonnlike plus $t y d$ plus kans. Monod werk self dic logicse konsek wensics van sy standpunt soos volg uit: "Chance alone is at the source of every innovation, of all creation in the biospherc. Pure chance, absolutely free but blind, is at the very root of the stupendous edifice of evolution ... If [man] accepts this message accepts all it contains - then [he] must at last wake out of his millenary dream; and in doing so, wake to his tolal solitude, his fundamental isolation. Now does he at last realise that, like a gipsy, he lives on the boundary of an alien world. $\Lambda$ world that is deaf to his music, just as indifferent to his hopes as it is to his sullerings or his crimes" 26 .

Nog 'n konsekwente Darwiniaans-naturalistiesc wetenskaplike is BF Skinner, dic bekende behavioristicsc siclkundige. Hy toon aan dat sy beskouings crnstige implikasies met betrekking tot menseregte het. Skinner postuleer ${ }^{27}$ 'n totaal-detcrministiese mensbeskouing: alle menslike gedraging is of vooral bepaal deur oorerflikhcid òf onmiddellik bepaal deur die omgewing. Dit het tans vir die mens moontlik geword om sy eie cvolusiegang oor te neem en dit deur grootskaalsc manipulasic te beheer ten einde menslike oorlewing te verseker. Idces ointrent menseregtc en menswaardigheid is egter 'n struikelblok en moct daarom afgeskaf word. Hy verklaar: "What is being abolished is autonomous man - the inner man, the homunculus man..., the man defended by the literatures of freedom and dignity" ${ }^{28}$.

Skinner is dan ook uiters ongeduldig teenoor diegene wat hom wil teenstaan op grond van bygelowige en onwetenskaplike begrippe soos menseregte - wat geen uiteindelike geldigheid of waarheid sou bevat nie en maar bloot ecn van dic toevallige produkte van evolusie sou wees en wat "afgeskal" moct word wanneer dit in die pad raak. Hy betoog: "A literature of freedom may inspire a sufficiently fanatical opposition to controlling practices to gencrate a neurotic if not psychotic response. There are signs of emotional instahility in those who have locen deeply affected by the literature" ${ }^{29}$.

${ }^{25}$ Mound (hance and necessity (vert 1971 ) 112 172-173 (corspronklik /e Llazard et la Néressite (1970)), aangehaal in Srliacfer Bnck to Freedom and Dignity (1973) 11-12.

27 Skinner Boyond Ficedom and Dignity (1971).

2n id 200 .

$2^{\circ}$ id 165. 


\section{Geregtigheid met betrekking tot gevangenes}

Skinner konkludeer dat oorlewing die enigste werklike waarde is ${ }^{30}$. Hy kan egter nie uil hoofde van sy lewensbeskouing (die onpersoonlike plus tyd plus kans) aantoon wárom die oorlewing van dic menslike ras nou juis van waarde is nie. Schaeffer lewer dic volgende kommentaar: "Skinner does not seem to notice that he has got hinself into a logical box. Ultimately, what he is saying reduces to whatever is, is right, and, if whatever is, is right, then there is no value over against which one can judge anything as gond or bad. If it is, it is good. And if everything that is, is good, then any concept of bad is either illogical or trivial ... [A] man like Skinner ... has [no] reason why the survival of the race is desirable" 3 !

Die skyn-waarde, oftewel futiliteit, van menseregte-idees wat, volgens die aannames van die naturalistiese lewensbeskouing, nes die mens selt bloot 'n produk van die onpersoonlike plus tyd plus kans is, word treffend beskryl deur nog een van die aanhangers van dié wêreldbeskouing, IIF Blackham: "On [these] assumptions, life leads to nothing, and every pretence that it does not, is a deceit. If there is a bridge over a gorge which spans only halfite distance and ends in mid-air, and if the bridge is crowded with human beings pressing on, one after the other they fall into the abyss. The br idge leads nowhere, and those who are pressing forward to cross it are going nowhere ... It does not matter where they think they are going, what preparations for the journey they may have made, hour much they may be enjoying it all'32.

Ingevolge die naturalistiese wêrelulseskouing is die mens nie kwalitatiel verskillend van die nie-mens nie: alles is bloot materie, en die nicns is maar net 'n ander rangskikking van molekules as die nic-mens ${ }^{33}$. Die mens het geen unieke waarde of waardigheid nie - al dink hy miskien so, soos Blackham supra dan ook insien. "Menseregte" is simneloos!

Teenoor die voorgaande wêrelelbeskouing met sy voorveronderstellings en konsekwensies moet die Bybelse wêreldbeskouing gestel word. Uiı die aard van die saak kan 'n verdediging of apologie vir hierdie beskouing nie binne

\footnotetext{
30 iil 31 .

31 Schaefler Back so Dignity (1973) 39.

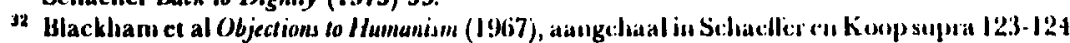

s3 Scluatfier en KJoup supra 124.
} 


\section{Jan H. van Rooyen}

die bestek van hierdic bydrac gegee word nie ${ }^{34}$. Dit dien egter wel gekonstatcer te word dat dit 'n lcwensbeskouing is met die volle konsekwensies unarvan 'n gelowige men.s betekenisunl en hoopvol kan saamleef. Sir Julian Huxley, 'n ateĩs, hrt byvoorbecldl verklaar dat 'n mens beter funksioneer indien hy optrec asof God bestaan ${ }^{35}$ !

In die volgende aftlelings word die huidige regsposisie met betrekking tor gevangenesrcgte ecrs geskets en daarna word aandag geskenk aan sommige van die implikasies van 'n Bybelse wêreltllseskouing vir dié onderwerp ${ }^{36}$.

\section{DIE IUUIDIGE REGSPOSISIE}

Met betrekking tot die Suid-Afrikaanse regsposisie ten opsigte van die regte van gevangenes, word in hierdie afdeling volst aan met 'n paar opmerkings, grknoop aan dic onlangs appèlhollseslissing in Goldberg $v$ Minisler of Prisons ${ }^{37}$.

Ingevolge bestaande reg word in Goldberg onderskci tussen (a) regte en (b) voorregte. "Regte" omvat dit wat noodsaaklik vir fisiese voortbestaan is, byvoorbecld voedsel, kleding, akkommodasie en mediese sorg, terwyl byvoorbecld biblioteck- en studcerfasiliteite bloot "voorregte" is. 'n Gevangene is nooit geregtig op voorregte nie; die kommissaris van gevangenisse het, prakties gesproke, feitlik 'n absolute diskresie omdat die huidige stand van ons administraticfreg nie voorsiening maak vir werklik betekenisvolle regterlike hersicning van 'n sogenaamde "suiwer administratiewe diskresic" nic 38 . In die arca van "voorregte" is die woord van die kommissaris as 't

"Vir inleidende sludie is Schaetfer en Konp supra, Guinness supra en Sire supra besonder nutlig, waarua die SclunefTer-trilogie supra (in linnine) met vrug bestudeer kan word. Van Irsondere hintoriese belang vir juriste is dic beroemde bewysreggeleerde Simon Grecnlear se "Ihe 'Testimony of the Fvangelists" (1903), licrilruk in Montgomery supra $91 \mathrm{cv}$

13 Kyk Scliaefer en Konp supra 139-140.

- Daar mort natumslik nie tit hierdie bydtac afgelei word dat geimpliscer word dat byvoorbeclel atcinte nie hot morele standaarde kan liandhaaf ol in menseregte kan glo nic, of dat byvoorbeclel nlle Christene hicraan voldorn nic. Feit is dat baic mense of nie die konsck wensies van hul voorveronderstellings deurdink nie, of nie daarvolgens leef of kan leef nie. Vir'n plrirlooi dat Cluristene 'n ounvattemile wereldbeskouing moet deurdink, vgl Runia 1970 Christianity Today 851.

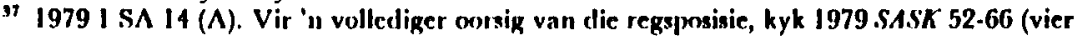
bydraes) en 1979 .SAL.7 640.

1n V $V_{B}$ die bydtaes in dic vorige voetnont passim. 


\section{Geregtigheid met betrekling tot gevangenes}

ware wet.

Die appellante (almal sogenoemde "politieke" of sckerheidsgevangenes) in Coldberg het gegrief gevoel oor die kommissaris se weiering om hulle toegang te gee tot leesst of wat aktuele nuus bevat (bchalwe nums met betrekking tot sport, familie en vriende). Hulle het onder andere gekla omdat die volgende tydskrifte waartoe hulle toegang vergun is, eers vooral "gesensor" is deurdat alle aktuele nuus verwyder is: Rooi Rose, Darling, Fair Lady, SA Garden and Home, Huisgenoot, Farmers' W'eekly, Landboutveekblad, Readers' Digest, Photography and Travel, Top Sport, Public W'orks Construction en Transport! In die lig van die huidige stand van ons reg, het hulle pleidooie misluk.

Die appèlafdeling was egter nie eenparig nie. Appèlregter Corbett het 'n indrukwekkende minderheidsuitspraak gelewer: "It is said that a prisoner has no right to study or to access to libraries or to receive books: that these facilities are privileges not rights, comforts not necessities. To my mind, this is an oversimplification. 'To test the proposition, suppose that an intellectual, a university graduate, were sentenced to the imprisonment and while in gaol was absolutely denied access to reading material - books, periodicals, magazines, newspapers, everything; and suppose further that there was no indication that this deprivation was in any way related to the requirements of prison discipline or security or the maintenance of law and order within the prison and that, despite his protests to the gaol authorities, he continued to be thus denied access to reading material. Could it be correctly asserted that in these circunstances he would be remediless? 'That all that he could do was to fiet for the comforts which he was denied? I venture to suggest that it could not be so asserted and that he would not be remediless" 39 .

Hierdie betoog, alhoewel nie deur dic mecrderheid anvaar nic, is (in die woorde van een kommentator) gebaseer op "unassailable reasoning" $\mathrm{cn}$ is vall groot belang vir toekomst ige ont wikkelinge met betrekking tol die regte van gevangenes.

34 Coldberg supra 4IF-H.

to Nairn 1979 SAASA 5863. 


\section{Jan H. van Ronyen}

\section{DIE AARD VAN DIE MENS}

Ingevolge die Bybelse wêr cldbeskouing bestaan daar 'n ewige, onmectbare dog persoonlike God. Hicrdic God het die mens in 'n afsonderlike skeppingsdaad na Sy beeld geskape. Dic mens het gevolglik 'n uniekheid, 'n mens-heid wat hom onderskei van nie-mens. Die implikasies hicrvan vir dic mens se waardighcid en vir menseregte is verreikend. Schacfler verklaar: "[W]e can see that all people are ... 10 be dist inguisherl from nonman and that therefore we ... must look on others as having grcat value ... Any person, no matter who he or she is - a st ranger or a friend, a fellow believer or somcone who is still in rebellion against God, anyone of any agc, before or after birth - any and every person is minde after the likeness of God" 41

Oor dic imago Dei, clic goddelike becld, is al baie geskrywe - veel meer as waarna hier verwys kan word. Dic goddclike beeld behels onder andere kennis en die uitbouing van kennis: die mens is, na Gods beeld, met intellektuele vermoëns belecld. Calvyn stel dit soos volg: "[T]he swiftness with which the human mind glances from heaven to earth, scans the secrets of nalure, and, after it has cmbraced all ages, with intellect and memory digests each in its proper order, and reads the future in the past, clearly clemonstrates that there lurks in man a something separated from the body"42.

Hy wys voorts daarop dal die mens nie maar net 'n dierlike bestaan voer nic, maar dat hy die lig van intelligensie besit.

Die Bybel verduidelik ook dat die mens geskend is. Die sondeval het naamlik verskeic abnormalitcile mecgebring: die mens is van God, van lıomself, van sy medemens, en van die natuur vervreem. Dit is egter van deurslaggewende belang om te bescf dat dic unicklıcid en waardigheid van die mens nie deur dic sondeval vernietig is nie, aangesien dit op die Skepping berus. Die beeld van God is nie totaal in die mens uitgewis nie ${ }^{43}$.

"Schacifer en Koop supra 158.

42 Calvy'n Institules of the Christian Roligion 1 15 (1536; 1962-vertaling deur 11 Beveritlge).

4. VRl Stub in 1974 Calvin Theolngical Journal I33 143: Sclinefter en Koop supra 153-155. Kyk Genesis 9:f cn Psalm 8; vgl ook die breedvoerige bespreking deur Murray getiteld "Man in the Image of Ged" in 2 Cillected Ulritings of John Mfurrar (1977) $34 \mathrm{ev}$. 


\section{Geregtigheid met betrekking tot gevangenes}

Die implikasies van voorgaande beskouings vir die regte van gevangenes is tweërlei. Eerstens: aangesien die fundamentele regte van dic mens op sy geskapenheid na die beeld van God berus, behoort dic inhoud van hierdic regte daarmee ooreen te stem". Ten einde die "mens"-heid van die mens van die dier te onderskei, behoort hierdie regte mér te omvat as die blote fisiese waarop byvoorbeeld 'n dierebeskermingsvereniging sou aandring (voedsel, kleding, akkommodasie en mediese sorg). Daar word met eerbied ter oorweging gegee dat ons Suid-Alikaanse regsposisie, soos hierbo kortliks uiteengesit, in hierdie opsig nog te kort skiet: die iuhoud van ons gevangenes se "regte" (onderskei van sy "voorregte") gee nie voldoende inloud aan die imago Dei nie. (Regter Corbett se aanhaling supra verdien alreeds in dié stadium 'n her-lees!)

Tweedens kan gevra word of ons benadering tot die regte van gevangenes genocgsaam rekening hou met die imago Dei-aard van die nens. Daar is twee radikaalverskillende benaderings moontlik met betrekking tot die regte van gevangenes. Aan die een kant kan 'n gevangene beskou word as "regteloos" - behalwe vir daardie regte wat noodsaaklik is ten einde fisies te bly leef. Enigiets wat verder gaan, is dan 'n blote geskenk van die owerhede, waarop hy nie geregtig is nie. Hierteenoor staan die beskouing dat 'n gevangene 'n gewone regsubjek bly en dat hom deur sy gevangesetting slegs sodanige regte ontneem word as wat streng gesproke deur die feit van gevangesetting genoodsaak word: die ontneming van regte is dus streng funksioneel. Volgens laasgenoemde benadering sou die reg oin op eie. onkoste en in vrye tyd te studeer, nie deur gevangesetting per se opgeskont word nie (dissiplinering in 'n geval waar 'n persoon sy studielsevoegdhede misbruik, sou vanselfsprekend geoorloof wees).

Van die twee benaderings hier genoem, skyn slegs die tweede in ooreenstemming met die imago Dei-perspektief te wees. Daar word gevolglik met eerbied betoog dat ons Suid-Afrikaanse benadering - wat met die eerstc ooreenstem - ook in dié opsig te kort skiet.

\footnotetext{
" "The Lasic Judaeo-Christian doc trinc of man made in the image of ( iod inplies lliat ol heis have a duty to treat him in the way which best belits his status" - Auderson liberty. I ant and Justice (1978) 57.
} 
Jan II. van Rooyen

\section{LEGALITEIT}

Ingevolge die Bybelsc beskouing betcken die begrip "legaliteit" primêr "na die orde van God se wet": dit vereis met ander woorde 'n regle (in Bybelse siil) manier van cloen deur menslike instellings ${ }^{45}$. Dic implikasics hicrvan is ecrstens dat menslike reg aan God se geregtigheidsbeginsel moet voldoen, en tweedcns dat die staat ook regsgebonde is.

Lnasgenocmde aspek is bclangrik indien in ag gencem word dat ook die staat radikaal deur die sondeval geaffeklcer is: die staat en sy funksionarisse is ook gevalle en feilbaar en gencig tot alle kwaad. Een van die funksics van reg in die algemeen is om as "algemene genadeniddel" te geld, dit wil sê om as 'n beperkende invloed ten opsigte van die gevalle menstom te geld en sodoende die uiterste konsekwensies en uitwerking van die sondeval teë te hou. Dit is gevolglik duidelik dat ook dic staat "onder die reg" behoort te wecs: princeps legibus solutus NON est! ${ }^{46}$.

Juis omclat ook dic owerheielsmens radikaal deur die sondeval geaffektcer is, is dit nie verbasend nie dat hy homself gedurig probeer outonoom maak, homself probecr verhef bó die reg: maksimum-owerheidsvryheid, regsongebondenheid, en absolute diskresionêre magte word gesoek. Uiteindelik bly daar van 'n Christelike legaliteitsvisic niks meer oor nie" ${ }^{47}$. Wiechers waarsku soos volg: "[D]ie opvatting dat sommige diskresies in 'n regsvrye gebied uitgeocfen mag worl .. druis lynreg teen die begrip van die regstaat cn dic regsgebonde staatsadministrasic in" ${ }^{48}$.

Dic voorgaande bring twee belangrike implikasies mee: Eerstens word bostaandle beginscls misken wanneer 'n sogenaamde "administraticwe diskresic" wat prakties absolutisties cn feitlik onhersicnbaar is, aan 'n

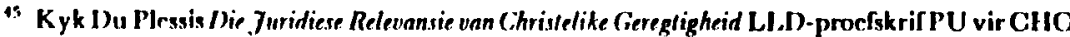
(1978) 649. Vglonk Marslıall Fels 19007 hird IIay 9; Dengerink 7he Idea of. Justice in Christian I'rrspectice (1978).

"Du Plessis supta 2019-210 7RR. Vgl onk Wiechers 1967 THRfIR 309 320: "[Dit is] 'n aanvaarde beginsel dat dic administrasir se aktiwiteite deur regerlike instansies gekontroleer moet word ten einde 'n maksimım regsualewing en beskerning van die individu se vryhede en regte te versekr". Vgl voorts deurgaans dic briljante bydrac van Gellhorn in dic verslag supra $181 \mathrm{cv}$.

"Dit I'lessis supra 793.

11 Wiechers Administratiefreg (1973) 231. 


\section{Geregtigheid met betrekking tot gevangenes}

amptenaar of aan amptenare toegeken word: dit kom neer op 'n verwydering van beheermaatreêls van mense wat wel goeie en opregte mense mag wees, maar wat, synde gevalle en feillsare sondaars, nogtans onder sodanige beheerınaatreëls geplaas behoort te word. Vergelyk die opmerking van Taitz: "It is unrealistic and unjust ... 10 place such blind faith in the innocence, competence and integrity of public officials ... Recent political events have indicated, once again, that public oflicials are subject to the same prejudices and temptations as ordinary citizens"19.

Duidelik geformuleerde, afdwingbare regsreëls met betlekking tot gevangenesregte - as 't ware 'n "Bill of Rights" - sou nie slegs legaliteit daarslel nie, maar sou ook betekenisvol tot dic instandhouding on betwaring van legaliteit bydra.

'n Tweede implikasie is dat die beskikbaarheid van en toegang tot 'n onafhanklike (onpartydige) en objektiewe regterlike arbiter tesaute met billike prosessuele en bewysregtelike reëls voorvereistes vir die belıoorlike handhawing of afdwinging van legaliteit is ${ }^{50}$. Die uiteindelike en linale beslissing oor die regte van persone binne 'n gevangenis-opset mag nic aan belangheblendes, soos gevangenisbeamples, oorgelaat word nic. Met eerbied, ons stelsel skiet ook hier te kort. Die howe behoort die effekticwe

19 Taiz 1979S.ASK 63 66. Vgl Psalm 146:3 - "Vertiou nic op prinse, op die mensekind, by wic geen heil is nie". Daar word naturilik nie geïmpliseer dat "n regles like bea nupe 'n elenent van onfeilbaarbeid sou meebring nie - dit is blout 'n addlisionele beveiligingsmeganismo (maar nogtans 'n baic belangrike cen).

so $V_{\text {gl }}$ Ruslıdoony Institutes of Biblical Law (1973) passim; Du Plessis supra 70; Wiechers supra 232-233. Du Plessis 824 wys daarop dat die rogenaande "reêls van nal uurlike geregtigheid" (bv audi alteram partem en nemo index in re sua) ten nouste mel die Bylselse geregtigheidsimperatief verband hou. Vgl cok Mlutaung v Mahubela 1975 I SA 610 (O). Die uweilieill is Suid-Afrika handhaal eienaardige dulshele staudaarde in hierdie opsig. Aan die cen kant, bv, bevestig VVO-ambassadeur Kiatan Bksteern op 25.5.1979 oor SA'I'V minister RF (Pik) Bollsa se mening dat "the audi alleram pan tem principle underlies all civilized legal systems" can bekla sekere partyc tot die Inligting-skandaal gerlureme 1979 hulle oot die vrystelling val "ongetoetsde getuienis", maar aan die ander kant word weigewing gehandloual wat uneuse hul vrylieid ontseem sonder dat hulle enige van hierdie basiest: regte gelsad liet, bv die We op Terrorisme 83 van 1967. In updrar vall 'n voormalige minister vall justisic skcyl' 'A atnptenaar, met betrekking tot die stelling dat dic geregtigheidsteginsel andi alteran

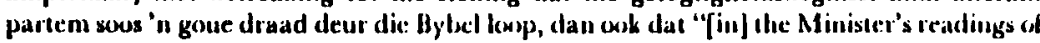
the Bible lie has never corne across this golden thread"! (Widef gedateet 2.11. 1978.) 


\section{Jan H. van Rooyen}

arbiters te wees".

\section{GEREGTIGHEID}

Tydens een van dic (lebatte in die volksraad met betrekking tot die afskalfing van studievoorregte vir sekerheidsgevangenes as 'n kategorie het dic volgende woordewisseling plangevind: Minister: "Ons het gevind dat sommige van hierdie mense dic sludiegclecnthede wat hulle gehad het ... misbruik". Opposisiclid: "Maar hulle kon dit seker nic almal misbruik het nie". Minister: "Ons het 'n besluit geneem in hierdie verband omdat die mense nie rehabilitcerbaar is nie". Opposisiclid: "Straf hulle almal vir die sondes van 'n paar!"52.

Slcgs 'n paar opmcrkings hoef hicr oor die begrip "geregtigheid" ("justice")

${ }^{31} \mathrm{Vgl}$ in dic algemeen met betrekking tot die beheer van administratiewe diskresic $A$ llen 7 he Borderland of Ciriminal Justice (1964); Culp Davis Disrretionary Justice (1968); Orland Justice, Punishment, Trealment (1973) en Pennock en Chapman (reds) Due Process (Nomos XVIII 1977). In wyer verband, $m$ b t die "rule of law" in die algemeen, vgl Dugard/luman Rights and the SA legal Order (1978), Mathews Law, Order and liberly in SA (1971), Van der Vyver Die Beskerming ran Afenseregle in SA (1975) en Van der Vyver.Seven Lectures on Human Rights (1976). I $\mathrm{m}$ menseregte in die algemeen, kyk die verslag lluman Rights: The ('afpe Toun Conferente (1979). Kyk ook Hermann en IIaft (reds) Prisonerr' Rights Source Book (1973); Zellick "The Case for Prisoners' Righes" in Freeman (red) Prisons Past and Future (1978) 105; en Fogel "Thr Justice Model for Corrections" in Freeman op cit 151. Daar word natuurlik nie betoog dat gevangeues oor beuselagtighrde die gevangenisalminist rasie hof toe moet kan neem nic. Fen moontlike benadering sou wees oin 'n behoorlike groep fundamentele regte uit te werk wat slege deur 'n holbevel in hoogs nitsonderlike gevallc opgeskort kan word. Privilegies sou in so '" stelsel onderworpe grmaak kon word aan "n "gebonde" diakresic waarvan dic sogenaamite "jurisdiksioncle feite" altyd deur 'n hof toetsbaar sou wees. Vgl Wiechers supra 231-232 298 ev. Vgl veral ook Culp Davis op cil vir voorstelle dat die owerhede se interne rerels en riglyne duidelik en beskiklsanr moet wees (wat natuurlik hersiening sal vergemaklik). In hierdie verband is regter Corbett se kritiek met betrekking tot die onbeskikbaarheid van die sogenaande "rexls" met bettekking tot sensorskap van leesstof in die (ioldherg-saak supra 45 opmerkenswaardig. Gellhorn sh iv m administratiewe besluitnemers: "An acljudicator's knowledge that he must explain his judgments has had markedly benefient consegurences in prison adeninistration, for the acjudicator is thus reminded be is performing a grave act that slould be based on conclusions related to evidence. A lesser requirement leaves too great room for whim, malice, or plain stupidity" - verslag supra 182

321978 (15) Hansard kolem 7018 (Afr.) 


\section{Geregtigheid met betrekking tot gevangenes}

as sodanig gemaak te word ${ }^{53}$. Die grondslag van straf lê in die beginsel van vergelding', 'n geregtigheidsbeginsel ingevolge waarvan (a) daar 'n bestaande reël (norm) is waaraan 'n strafbepaling gekoppel is wat oortree moet word voordat straf toegerneet mag word (die nullum crimen sine lege-beginsel); (b) slegs diegene wat werklik skuldig is gestraf mag word (nulla poena sine culpa); en (c) die straf nie swaarder moet wees as wat die oortreder "verdien" nie (die "oog om oog en tand om tand"-beginsel stel 'n perk op straf: nie méer as 'n oog om 'n oog en nie mér as 'n tand om 'n tand nic).

'n Aantal praktiese implikasies vloei uit die geregtigheids- of vergeldingsbeginsel voort:

- Daar moet konkrete regsreëls wees wat dit vir elke gevangene duidelik maak wat sy verpligtinge is; dié reëls moet behoorlik onder sy aandag gebring word en hy behoort gereeld toegang daartoe te hê $\hat{e}^{55}$.

- Die verantwoordelikheid van gevangenes om die reëls te gehoorsaam, is 'n persoonlike verantwoordelikheid. Ruslıdoony stel dit só: "[G]uilt cannot be shifted to others or passed on to the people around a man. Guilt is non-transferable. A disposition or nature can be inherited, but not guilt. Man inherits from Adam the total depravity of his nature, but his guilt before God is entirely his own, even as Adam had to bear his own guilt. This distinction between guilt and nature is fundamental to Biblical doctrine and law ... Since the law deals with guilt and punishes the guilty, the

53 Daar is natuurlik 'n noue verband eussen hierdie en die vorige afdeling.

34 Dit word ter oorweging gegee dat slegs vergelding (ouk die "gelegtigheidst corie" genoenu) aan straf 'n bevredigende morele grondslag verskaf. Dit beteken geensins dat die ander strafteorice betekenisloos is nie. Hulle moet eerder gesien word as doelstellings met/tydens straf. So is dit bv moontlik om op die grondslag en binne die perke van die vergeldingst eoric terselfdertyd algemene afskrikking (general deterrence), ontrekking (incapacitation) eu rehabilitasie te bereik. Die vergeldingsteoric impliseer ouk gecnsins atralsugtigheid nic; oorweging: sook genade en strafekonomie speel ook 'n wol. Stralekonomic vereis dat die groutste moontlike aantal rasionele cogmerke unet of tydeus straf nagestreef moet word, binue die grense van vergelding. Kyk iv in die geregtiglteidsteorie (vergeldiug) Armstrong "Ihe Retributivist Hits Back" in Grupp (red) Theories of Punishment (1971); Lewis "Ihe Humanitarian Theory of Punishment" in Grupp op cit; Morris The Future of Imprisonment

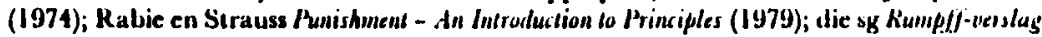
RP 69/1967 en die sy Viljoenuerslag RP 78/1976. Vgl ook in dic algemecon Allen supra.

ss Wat die inhoud van die reêls betrel, is die voorgaunde dele van hierdie teleraat slecils relevant. 


\section{Jan 11. van Rooyen}

non-transferable nalure of guill... is of central importance" ${ }^{56}$.

- Alle mense is geregtig op geregtigheid, ork gevonnisde oortreders. Dic geregtigheidsheginsel word nie opgeskort wanneer die tronkdeure tocgegrendel word nie. Deuteronomium 1:17 stel dit sơ: "Julle mag in dic gereg nic partydig wees nie; julle moct klein sowel as groot aanhoor". Waar sommige "politicke" gevangenes geen geregtigheid tecnoor hul slagoflers betoon liet nie; is dit juis in die teken van Bybelse geregtigheid dat die owcrheid nic inspelyks optree nic, maar Bybelse gercgtigheidstandaarde deurgaans handhaaf.

Dic gevolgtrekking is duidelik. 'n Gevangene wat die reëls oortree het, mag gedissiplinecr word; dic een wat sy studieregte misbruik het, mag sy studieregte ontueem word. Maar ingevolge'n Bybelse geregtigheidsbegrip mag 'n hele kategorie mense nie hul regte ontneem word bloot omdat sommiges daardic regte misbruik nic, oftewel die reëls met betrekking tot die uitocfening daarvan oortrce het, nic. Dit sou geen geregtigheid daarstel nic, maar wel onreg.

\section{REHABILITASIE}

Slegs agt en dertig van die huidige sogenoende sekerheidsgevangenes dien lewenslange gevangenisstraf uit. Die res - meer as 150 - sal die een of ander tyd vrygelaat word en hulle weer in die gemeenskap bevind ${ }^{37}$.

Hoewel vergelding dic grondslag van straf is, hehoort rehabilitasiemoontlikliede nog stecds tydens straf beskikbaar gestel te word - ook binne gevangenisverband ${ }^{58}$.

Daar word dikwels gesê dat "rehabilitasie" van sckerheidsgevangenes baic mosilik is ${ }^{59}$. Dit is scker so. Desnietecnstaande mag 'n mens, ingevolge die

56 Risslidonny supra 270 (my beklemtoning). VRl nok Deut 24:16. (Goddelike genade, wrerspircl in (hliristus wal as $\mathrm{L}$ a m van (jot vrywillig die wereld se sondex op homself geneem het, is nat tuurlik nie nou ter sprake nic.) $V_{R} l$ verier die klem wat op menslike verantwoordelikheid geplaas word deur Fulter The Morality of Law (I964) 162 ev.

57 Kyk 1980 (I0) Ilansard vrackoloin 628 (Eng).

S4k un 54 supra. Vol onk Goldlerg en Morris 1976 (IJSA 26 ev en Morris supra.

50 'n Minister van gevangenisse het gese dat dit mmmontlik is - kyk teks supra by vn 52. Jic beskiklare statistiek steum hom rgter nir - kyk teks supra by vn 7. 


\section{Geregtigheid met betrekking tot gevangenew}

Bybelse begrip van genade - God wat op vrymagtige wyse genadiglik kan ingryp in menslike tyd en ruimte - egter nooit 'n hele kalegorie gevangenes afskryf as "onrehabiliteerbaar" nie ${ }^{6 n}$.

Baie van die sekerheidsgevangenes is intelligent genoeg om baat te kan vind by verdere formele studie binne die Suid-Afrikaanse opvoedkundige stelsel ${ }^{61}$. Dit is voots moontlik dat frustrasie as gevoly van ontneemde studiegeleenthede tot groot verbittering by intelligente langtermyn-gevangenes $k$ an $l \mathrm{ei}^{62}$, wat reluabilitasie in dic wiele sal ry en wat aldus uiteindelik individuele voorkoming (dit wil sê voorkoming van herhaling van die misdadige gedrag) wanneer die gevangene hom weer in die gemeenskap bevind, kan skaad.

Wanneer vrygelate sekerheidsgevangenes hulle weer in dic gemeenskap bevind, is hulle soons aan sekere wetlike inperkinge onderhewig (byvoorbeeld ingevolge die Wet op Binnelandse Veiligheid 44 van 1950) en kan hulle gevolglik nie oor 'n wye veld werk soek nic. Vir baie mag ongeskoolde arbeid, vanwee hul intelligensie en aanleg, nie aangewese wees nie. Indicn hulle geen studieregte in die gevangenis gehad het nic, is hulle ook nie toegerus vir geskoolde betrekkings nie.

Wanneer 'n intelligente vrygelate gevangene aldus verbitterd, ingeperk en ongekwalifiseerd is, word herintegrasie baie bemoeilik, indicu nie volslac onmoontlik gemaak nie.

6" So "I louding sou ook 'n onaanvaarlare rol kan speel met betlekking tor die hantering van sckerlıeidsgevangenes en moet gevolglik cook on elié reile afigewys word. V'gl dic verslatg Prisons and Prisoners in England Today(1978) 44:"|T'|here is a real dasiger that this group |d w s die 'gevaarlike' langtemnyers] will be inplicitly 'written ofl' as luman leving's with a capacity for growth and change".

- Studie vind natuurlik nie in die plek van die mormale gevangenisprogram pluas nit, maar ma-uus, nadat die gevangenes hulle diaglikse vespligtinge afgehandel het.

"When a confined person's enviroument appears to tahe on matevoleut of even perseculory characteristics, we find not only adverse, but severely debilinating physical and psychological eflects" - McKay et al The tilfocls of Longerm Incarcenation (1979) 51 . Vgl id 53 vir rlic standpunt dat toegang 101 "sensory and cognitive stimulation" luudancuted vir dic welsyn van langtermyn-gevangenes is. 


\section{Jan II. van Rooyen}

Ilocwel dic "geregtighridsmodel" trn anusien van straf nie gedwonge behandeling binne gevangenisverband ter nastrewing van rchabilitasieoogmerke aanvaarbaar vind nic ${ }^{63}$, is dit aan dic ander kant duidelik dat "iit gebreide fasiliteitc ter selfverbetcring cu reliabilitasic tydens gevangenisstraf beskiklaar gestel behoort te word ${ }^{\text {64 }}$ sodat die gevangenisdepartement nie selfverbeterings- en rehabilitasiepogings verhinder nie - en dit sluit ná-Inatrickopleiding in, wat in dic tcenswoordige samelewing 'n noodsaaklikheid geword het en nie as 'n blote luuksheid beskou moet word nie. Reël 77 (1) valn dic VVO se. Standard Minimum Rules for the Trealment of Prisoners and Related Recommendations (1955), wat deur Suid-Afrika onderskryf word, bepaal dan ook dat (p) rovision shall be made for the further education of all prisoncrs capable of profiting thereby" en reël 77(2) lecs: "So far as practicable, the education of prisoners shall be integrated with the cducational system of the country so that after their release they may continuc their education without difliculty".

\section{SLO'T}

In hierdic bydrae het die skrywer sy eerste tree gewaag in die rigting van 'n algemene Bybelse menscregtebeskouing. Die belangrike rol van voorveronderstellings cn wêreldbeskouings is kortliks aangedui. Daar is in ietwat mecr besonderhede aandag geskenk aan 'n klein onderafdeling met betrekking tot dic regte van 'n klein onderafdeling van Suid-Afrika sc gevangenisbevolking ${ }^{65}$, te wcte studie- en leesgeleenthede vir sekerheidsgevangenes. Daar word terdeé besef dat die laaste woord oor reg en geregtigheid met betrekking tot gevangenes nie gespreck is nie. Trouens, daar is nic méer gedoen as om 'n paar kuntocre van 'n Bybelse reg- en

B) Kyk supra vn 54 met besondere verwysing na Lewis en Morris se werke, asook Coldlserg en Motris supra vn 58 .

54 Kyk teks supra by vn 58 . Argesien van enige utilitere, waarde van studie, moet dit, in die lig van die aaıd van (lie incoss (supta brlıandel), as van waarde op sigself gesien woud. $V_{g l}$ aanbeveling nr I van 'n Australiese interdepartementele komitce: "IT the inain aim of rducation for puisoners is the value (intellectual, cunotional or social) which arises from the learning arlivites" - verslag Prisoner Eduration in Snuth Australia (1978) 42.

6" Volgens die jongste jaarveıslag van die kummissaris van gevangenisse, is dic huidige daaglikse grwiddelde getal gevangenes in Suid-Afi ika so ongevecr 250 gevangenisse 98292 In eru jaar word 274001 grvomniste gevangenrs tot ons gevangenisse toegrlaat. Kyk RP 36/19m0 


\section{Geregtigheid met betreklsing tot gevangenes}

geregtigheidsperspektief uit te stippel nie. Verdere werk, uithouing en verfyning is noodsaaklik ${ }^{66}$. Voorlopig word dus slegs die volgende aanbevelings gedoen:

(a) Dat in beginsel besluit word oin weg te beweeg van 'n stelsel van feitlik absolute, ongebonde diskresic, na 'u omvattende stelsel vir die daarstelling en handlıawing van legaliteit en geregt igheid binne ons gevangenisstelsel ${ }^{67}$.

(b) Vir so 'n stelsel is die daarstelling van 'n omvattende menseregtchandves vir gevangenes noodsaaklik.

(c) Die inhoud van sodanige haudves bchoort in ooreenstemming te wees met die Bybelse beskouing van die mens as geskape na die becld van God.

Vergelykende studie toon aan dat soortgelyke ontwikkelinge reeds in ander lande aan die gang is ${ }^{64}$. Wat studiegeleenthede betref, is dit onder andere in Engeland blykbaar amptelike beleid orn uok persone wat weens sedisic tot gevangenisstraf gevonnis is, aan te moedig om verder te stucleer ${ }^{\text {by }}$. Die solisiteur-generaal van Kanada het onlangs voorgestel dat die volgende beginsels algemeen moct geld:

- "Deprivation of liberty resulting from sentence to inprisonment constitutes the punishment. Thus an inmate relains all the rights and responsibilities, of anyone else, except those taken away by statue as the necessary consequence of incarceration.

- Every effort should be made to strengthen family and community ties outside the institutions, and to lessen those aspects of imprisonment which lended towards the physical or menlal deterioration of immales.

"Die aanbring van verbeteringe sal nie die "doen van getegtiglocid ad infinitum" wataborg nic en gevolglik sal "weer en weer on relormasic en vernuwing" geroep moet word: "Sianper reformandun!" was trouens een vall dic keele van die Hervorming. Vgl Du l'lessis supra 773.

"Hierdie aanbeveling noct in die konteks van hierdie bydjae gelecs word. Kommentaar word nie noodwendig gelewer op die departement van gevangenisse se monale interne dissiplineringsprosedures nie.

6" Kyk bv Hulser 1978.SASK 229; Van Wyk IO79.S.ASK 52; Van Wyk Mci I979 Codicillus 8, Vgl voot ty die ornvattende bibliograliese werk deur I.evine Stundands of Giane in . Idull and, Jurenile Correctional Institutions (US Iept of Justice 1980)

69 Kyk supra vn 5 koloni 780 . 
Jan H. van Rooyen

- Corrections should try to bring about 'positive change' in offenders through opportumities and incentives as well as fairness in applying rules and regulations" 70 .

Hicrlic hydrac moet nie gesien word as 'n aanval op dic Suid-Afrikaanse gevangenis-owerliede nic. 'Trouens, ek is bewus daarvan dat dié departement tmet talle probleme worstel waarvan hulle nie self dic oorsaak is nic en het groot waardering vir talle aspekte van clie werk wat deur hulle verrig word. Met betrekking tot die gevangenisowerhede moet die insig van LM du Plessis met betrckking tot dic bevrydende waarde wat erkenning van menscregte en die daarstelling van oopheid, tocganklikheid, legaliteit en doeltreffende meganismes vir geregtigheid vir die betrokke owerheidsinstelling sel[ mcebring, gestel word: "[II]icrdie ware vryheid neem dic plek in van die angsvalligheid wat gewoonlik met dic skepping van 'n (skyn-) 'ruimte' vir gesagslunksionering-dcur-dwang gepaard gaan"11.

Ten slotte moet gemaan word dat 'n té maklike en gemaklike absolute tweespalt tussen ons en sekerheidsgevangenes - "ons" tcenoor "hulle" -nic getrek kan of mag word nie: "The reality is that both the oflender and the law-abiding community need to change and can change, a perception which is at the heart of some recent thinking about the society of crime and punishınıent"72.

\footnotetext{
7n Mci 1979 Linison 14 (my beklemtoning). Hocwel die daarstelling van handveste van menseregte en dic skeiding van staatsmagte met regbanke wat werklik funksionecr, nic onderskat moet word as middel ter bereiking van geregtigheid nie, moet ook erken word dat sodanige verbeteringe nie nooduendiz die doen van geregtigheid kan waarborg nic: "Geregtigheid is immers primer... geen saak van slrgs instellings nie maar van die bekecrde cn Iewente nenslike hart in 'n religieuse rigting tot die doen aan die naaste" - Du Plessis supra 820.

11 Du Plessis supra 779. Vgl ook die verslag supra vn 60 passim.

"Verslag supra vin 6070 .
} 